\title{
Editorial: Underground urban development and geoenvironmental issues
}

Frederic L. Pellet MSC, PhD, DSC, ASCE

Professor, Mines-ParisTech, Paris, France

Today, it is estimated that more than half of the world population lives in cities and the trend indicates that urban populations will continue to increase in the decades to come. The development of megacities with more than 10 million inhabitants will therefore continue at a steady pace.

Available surface space for urban development will become increasingly scarce and one option is to build below the ground. The use of underground space, however, raises many questions of an architectural, technical, environmental, socio-economic and legal nature. In addition, the use of the subsoil as a credible and sustainable alternative for urban development requires in-depth knowledge of the subsoil itself. Consequently, advanced urban planning guidelines must be established to optimise the synergies between the surface and the subsoil (Labbé, 2016). Several international programmes, like those promoted by UN-Habitat, have begun to address these questions (UN-Habitat, 2016).

Among the many environmental issues brought about with underground facilities in megacities, one of the most important is the need to understand the geotechnical conditions in order to avoid damage to existing buildings and infrastructures, and to prevent harmful actions to the natural biosphere. The question of protecting and managing underground water resources is of the utmost importance, as is the management and reuse of excavated soils and rock. All of these issues require comprehensive and innovative geotechnical solutions.

Some of these solutions are outlined in the current Environmental Geotechnics issue. Wagner and Scheuermann (2017) present a new technique using electromagnetic waves to better characterise soils and weathered rocks. Islam and Shang (2017) propose electrokinetic thickening tests for dewatering mature fine oil sand tailing. Castelli et al. (2017) propose a new tool to investigate landfill and solid waste, and Kog (2017) presents a case of rehabilitation of a large area of land. Additionally, Quek et al. (2017) examine feasibility of land reclamation with incineration bottom ash waste in Singapore.

Another major concern for urban development is the need for clean and renewable energy. The objectives set out at the recent United Nations Conference on Climate Change (COP21) aim to reduce green house gas emissions. Recently, Environmental Geotechnics devoted an issue to energy geostructures (August 2016, Volume 3, Issue 4) with a comprehensive editorial from M. Barla and A. Di Donna (2016) who emphasised the urgent need to meet both the growing energy demand and the air pollution reduction. The papers in this issue highlighted shallow and subsurface geothermal installations, which represent much of the potential gains in clean energy as it was emphasised in a remarkable paper by Hytiris et al. (2017). At the same time, some projects are planned for deep geothermal energy exploitation (Pellet, 2016). However, in urban areas the risk of inducing seismicity by changing pore pressure within the rock basement (Selvadurai, 2015) has to be properly assessed to avoid triggering earthquakes. This is what happened in 2006, in the city of Basel (Switzerland), where water pumping and reinjection operations triggered a 3.4 magnitude earthquake (Terakawa et al., 2012). Another important point is the need to undertake risk management assessment for cities located in mountainous regions (landslides) or built in seismic zones (earthquakes). For example, in the current Environmental Geotechnics issue Fannin et al. (2017) show how debris flow could be modelled to predict their travel distance and to mitigate their damaging consequences on downstream facilities. All of the aforementioned problems can be addressed using geotechnical expertise, which can provide valuable insights to help mitigate cities' vulnerability.

In France, the large project, 'Grand Paris', with 12 million inhabitants, has been launched; 1.5 million new housing units will be constructed over the next 25 years. The transportation network, used by 8 million people each day, will be modernised and three new metro lines will be constructed for a total of $200 \mathrm{~km}$ of tunnels.

There is no doubt that such projects will provide great opportunities for the further development of environmental geotechnics.

\section{REFERENCES}

Barla M and Di Donna A (2016) Editorial. Environmental Geotechnics 3(4): 188-189, http://dx.doi.org/10.1680/jenge.2016.3.4.188.

Castelli F, Lentini V and Maugeri M (2017) Dynamic characterisation of municipal solid waste by SDMT. Environmental Geotechnics 4(1): 9-18, http://dx.doi.org/10.1680/envgeo.13.00121.

Fannin RJ, Mickovski SB, Stokes A, Eliadorani AA and McConnell R (2017) Debris flow behaviour and travel distance: $\mathrm{Col}$ du Sabot, France. Environmental Geotechnics 4(1): 19-26, http://dx.doi.org/10.1680/ envgeo.14.00042.

Hytiris N, Ninikas K, Emmanuel R, Aaen B and Younger PL (2017) A heat energy recovery system from tunnel waste water. Environmental Geotechnics, http://dx.dx.doi.org/10.1680/jenge.15.00087.

Islam S and Shang JQ (2017) Electrokinetic thickening of mature fine oil sands tailings. Environmental Geotechnics 4(1): 40-55, http://dx.doi. org/10.1680/envgeo.15.00008.

Kog YC (2007) Rehabilitation of abandoned non-hazardous tailings ponds. Environmental Geotechnics 4(1): 27-39, http://dx.doi.org/10.1680/ envgeo.14.00051.

Labbé M (2016) Architecture of underground spaces: From isolated innovations to connected urbanism. Tunnelling and Underground Space Technology 55: 153-175, http://dx.doi.org/10.1016/j.tust.2016.01.004. 
Pellet FL (2016) Rock mechanics' contribution to environmental geotechnics. Environmental Geotechnics 3(3): 140, http://dx.doi. org/10.1680/envgeo.13.00119.

Quek A, Wu D, Xu W and Guo L (2017) Feasibility of Singapore IBA waste for land reclamation. Environmental Geotechnics 4(1): 56-64, http://dx.doi.org/10.1680/jenge.15.00012.

Selvadurai APS (2015) Normal stress-induced permeability hysteresis of a fracture in a granite cylinder. Geofluids: Special Issue on Crustal Permeability 15(1-2): 37-47.
Terakawa T, Miller SA and Deichmann N (2012) High fluid pressure and triggered earthquakes in the enhanced geothermal system in Basel, Switzerland. Journal of Geophysical Research 117: B07305.

UN-Habitat (2016) http://unhabitat.org/cooperation-agreementpromotes-sustainable-use-of-underground-urban-space/ (accessed 15/12/2016).

Wagner N and Scheuermann A (2017) Electromagnetic techniques in geoenvironmental engineering. Environmental Geotechnics 4(1): 3-8, http://dx.doi.org/10.1680/envgeo.13.00104. 